\title{
Revisiting Ghana's 2008 Presidential Run-Off Election
}

\author{
Ntim Gyakari Esew \\ Department Of Political Science Faculty Of Social And Management Sciences Kaduna State University, Kaduna
}

\begin{abstract}
Election is the major means through which representatives are chosen by the electorate. It is, therefore, the medium by which there can be a peaceful transfer of power from one government to another. Several elections have been held in Ghana since 1946. The thrust of this paper however, is to critically review the 2008 Presidential run-off between Nana Akuffo-Addo of the then ruling National Patriotic Party (NPP) and Prof John Evans Atta mills of the National Democratic Congress (NDC) and its implications for democratic consolidation in Ghana. Relying solely on secondary sources for data the paper reveals that the discovery of oil and the denial of the NDC of power for nearly a decade heightened the tension between the two parties especially in the two run-offs.
\end{abstract}

Key Words: election, run-off, Contestants, Tain, front-runners

\section{Introduction}

Having broken the jinx of civilian-to-civilian transition in January 2001, Ghana is gradually becoming a beacon of hope for democracy not only in the West African sub-region but on the African continent as a whole. For a period of eight years (2000-2008), the New Patriotic Party (NPP) had taken over the reins of power from the ruling New Democratic Congress (NDC). The first Presidential Election Run-off in the Fourth Republic was between John Agyekum Kufuor of the NPP and John Evans Atta Mills of NDC and it took place in December, 2000. This election was dubbed 'John versus John'. The former defeated the latter in that run-off election. The second one was in 2008 between John Evans Attah Mills of the major opposition party, NDC, and Nana Akuffo Addo of the ruling NPP. In both instances, there had to be run-off because neither of contestants secured the mandatory $50+1 \%$ votes to emerge as the outright winner.

This paper critically examines Ghana's 2008 Presidential Run-off Election between the ruling NPP's Nana Akuffo Addo and the major opposition party's John Evans Attah Mills. Interest was kindled in this runoff election because it was the first time in the nation's political history that Presidential Election had gone into the third round. Election plays a very crucial role in representative democracy because it is the medium through which candidates are elected to represent citizens in the legislative and executive arms of government. The importance of elections, therefore, cannot be over-emphasized and that is why states that even operate one-party system still subject candidates to elections so that members of the legislature as well as those of the executive will have legitimacy.

It must be pointed out that both local and international observers who monitored the run-off election noted that as far as humanly possible, it was free and fair. Much as this was the verdict, the run-off election brought out certain covert and veiled fragilities of the Ghanaian State to the fore and it is these that the paper tries to unveil. Data for this research is primarily from secondary sources relying mostly on the mass media and content analysis of published and unpublished works that are related to it.

The paper is divided into six sections.

The first is the introduction above which is followed by Conceptual Clarification and Theoretical Framework respectively. Fourthly, light will be shed on previous Presidential Run-offs in Ghana paying attention to the role of the media and political foot soldiers. The last but one section is on the 2008 Presidential Run-off Election itself while the last is the conclusion.

\section{Conceptual Clarification}

The two major concepts to be explained here are elections and run-off.

\section{Election}

Election in its most inclusive form according to Inokoba and Kumokor (2011:140 quoted) is defined as a form of procedure recognized by the rules of an organization whereby all or some of the members of the organization choose a smaller number of persons or one person to hold office or authority in the organization. 
Throwing more light on the political definition of election, they note that it is institutionalized procedures for choosing political office holders by the electorate of a country i.e. it is the means through which the electorate chooses their representatives into different organs (positions) of the government ( Inikoba and Kumokor, 2011:140 cited).

The foregoing definition is corroborated by Bain (1964:162 cited in Irokoba and Kumokor, 2011:140)) who sees election as

The formal process by which the electorate selects officials and determines the issues submitted to it. It is, therefore, a procedure for choosing officials or making binding decisions concerning policy by the vote of those who were formally qualified to participate.

In another vein, to Gwinn and Nortan (1992 cited in Oddih, 2007:152), election is the formal process of selecting a person for public office or registering a political proposition by voting. Elucidating further, they maintain that an election is one of the means by which a society may organize itself and make specified formal decisions...(and) where voting is free, it acts simultaneously as a system of making certain decisions regarding the power relations in a society, and as a method for seeking political obedience with a minimum of sacrifice of the individual's freedom.

And Eya (2003 cited in Oddih, 2007:153) concurs with the definition above by pointing out that election is the selection of a person or persons for office by ballot and making choice as between alternatives.

The definition of election by the World Book Encyclopedia (2008:158) is apt for our discourse. It perceives election as the process by which people vote for the candidate or proposal of their choice...Elections thus rank as one of the most important political activities ... and serve as a means of peaceful transfer of power from one person or group to another.

From all the definitions of elections above, the common cord running through them is the act of making choices from given alternatives. The few that are chosen thereof are entrusted with authority to act on behalf of those who selected them. McKenzie (1972) aptly points out that it is possible thus to speak of elections in general as a 'ritual choice'; the binding character of elections derives from the participation of an individual as a chooser in social act, and legitimate authority thus conferred on the person chosen. All the clarifications above indicate that election is an important component of democracy.

\section{Run-off Election}

To Johari (2003:480) a run-off election is also known as Second Ballot System. He points out that in case no candidate gets clear majority of the votes polled...the election is cancelled and re-election takes place in which two persons with the largest number of votes are allowed to contest again...In any case, the contest is between two candidates and thus the winner gets absolute majority of the votes in the second ballot.

A run-off election is also defined as a final election which usually occurs when an initial election does not produce an outright winner (Ask.com 26/02/2014@.22hrsgmt). In other words, it is a final election that occurs when an initial election does not produce a winner (Davemanual.com).

It is sometimes...held when there are three or more candidates and none of them won majority of the votes. It is another election between just the two top vote getters, held weeks after the first election, at great expense and usually with a lower voter turn-out. It allows a selection between the choices receiving the largest and second largest number of votes in the original balloting (uslegal.com/r/run-off_election) .

Bouton (2013) has written extensively on run-off elections. He observes that in a run-off election, the candidate with the greatest number of votes wins outright in the first round if he/she obtains more than a predefined fraction of the votes (called the threshold for first round victory ) which in Ghana is more than $50 \%$ of the total valid votes cast. If no candidate wins in the first round, then a second round is held between the two candidates with the most first round votes. The winner of that round wins the elections. He maintains that the run-off electoral system is the single most used electoral system for Presidential Elections: that 61 out of 91 countries that directly elect a President have a run-off provision (Bouton, 2013:1248).

\section{Theoretical Framework}

This paper is premised on Elections Theory propounded by Alberto Simpser (2013) in his book,' Why Governments and Parties Manipulate Elections: Theory, Practice and Implications'. The central argument of his theory is that in many instances elections are about more than winning. With copious data he argues that electoral manipulation is not only a tool to gain votes but also a means of transmitting or distorting information. This manipulation conveys an image of strength shaping the behaviour of citizens, bureaucrats, politicians, parties, unions and business people to the benefit of the manipulators increasing the scope of the manipulators to pursue their goals while in government and mitigating future challenges to their hold on power. 
This theory is relevant to this paper because throughout the run-offs there were accusations and counter accusations and the use of propaganda from both the NPP and NDC. And at the end of the day the NPP not only boycotted the Tain elections but took the case to court.

\section{Previous Presidential Run-offs in Ghana}

The first ever Presidential Run-off Election was held in Ghana during the short-lived Third Republic, 1979-1981, on $9^{\text {th }}$ July, 1979 between Dr Hilla Limann of the People's National Party (PNP) and Mr Victor Owusu of the Popular Front Party (PFP). In the general elections held on $18^{\text {th }}$ June, 1979, there was no outright winner.

The Table below shows the results of the 1979 Presidential Elections (First Round)

\begin{tabular}{|l|l|l|l|}
\hline Candidate & Party & Votes & Percentage \\
\hline Hilla Limann & Peoples National Party & 631,559 & 35.32 \\
\hline Victor Owusu & Popular Front Party & 533,928 \\
\hline William Ofori Atta & United National Convention & 311,265 & 29.86 \\
\hline Frank Bernasko & Action Congress Party & 167,775 & 17.41 \\
\hline Ibrahim Mahama & Social Democratic Front & 66,445 & 9.38 \\
\hline John Bilson & Third Force & 49,104 & 3.72 \\
\hline R.P. Baffour & Independent & 8,812 & 2.75 \\
\hline Kwame Nyanteh & Independent & 8,480 & 0.49 \\
\hline Mark Diamond Addy & Independent & 5,959 & 0.47 \\
\hline Imoru Ayana & Independent & 4,874 \\
\hline Total & & $1,788,209$ \\
\hline
\end{tabular}

Source: Ghana Electoral Commission 1979

From the table above it can be seen that the two candidates with most first round votes were Hilla Limann and Victor Owusu of the PNP and PFP respectively. These two front runners were therefore, pitched against each other in a run-off on $9^{\text {th }}$ July, 1979 and it was won by Dr Hilla Limann of the PNP with $1,118,305$ representing $62 \%$ of the total votes cast while Mr Victor Owusu of the PFP secured 696,097 representing 38\% of the total votes cast.

The table below shows the results of the 1979Presidential Run-off Election:

\begin{tabular}{|c|c|c|c|c|}
\hline REGION & $\begin{array}{l}\text { DR. HILLA LIMAN NO. OF } \\
\text { VOTES WON }\end{array}$ & $\%$ & $\begin{array}{l}\text { MR. VICTOR OWUSU NO. OF } \\
\text { VOTES WON }\end{array}$ & $\%$ \\
\hline Greater Accra & 140327 & 72.56 & \begin{tabular}{|ll}
53 & 073
\end{tabular} & 27.44 \\
\hline Ashanti & 114450 & 42.31 & 196933 & 57.69 \\
\hline Brong/Ahafo & $77 \quad 203$ & 38.29 & 124496 & 61.71 \\
\hline Central & 115395 & 70.97 & $47 \quad 209$ & 29.03 \\
\hline Eastern & 128765 & 55.80 & 101976 & 44.20 \\
\hline Northern & 105881 & 66.21 & $54 \quad 033$ & 33.79 \\
\hline Upper & 130688 & 74.33 & $45 \quad 137$ & 25.67 \\
\hline Volta & 149529 & 85.57 & $25 \quad 224$ & 14.43 \\
\hline Western & 126067 & 76.80 & $38 \quad 076$ & 23.20 \\
\hline TOTAL & 1118305 & 61.98 & 686097 & 38.02 \\
\hline
\end{tabular}

Source: Ghana Electoral Commission, 1979

It can be inferred from the table above that Hilla Limann of the PNP won in all Regions but Ashanti and Brong Ahafo.

\section{Fourth Republic}

In the first General Elections of the Fourth Republic, the Presidential Election preceded the Parliamentary Elections. The elections were conducted in two phases: the Presidential in November and the Parliamentary in December (Esew, 2001:250).

It is on record that the first two Presidential Elections of the Fourth Republic, 1992 and 1996, were won outright by Jerry John Rawlings on the ticket of his party, the NDC. However, since the 1992 Constitution forbade him to go for a third term in 2000, Prof. John Evans Atta Mills was nominated to run for the Presidency on the ticket of the NDC. Esew (2001:258) reiterates that the maximum term of office for Jerry John Rawlings expired in 2000, having ruled for two terms of four years each. He was, therefore, not qualified to present himself again as a candidate... and he handed over the baton to his Vice, Prof Atta Mills. The major opposition Party then was the NPP whose Presidential candidate was Mr John Agyekum Kufuor. In all seven candidates contested for the Presidential seat. The outcome of the first round is found below. 
Table showing the Results of the Presidential Elections held on $7^{\text {th }}$ December, 2000. ( $\left(1^{\text {st }}\right.$ Round $)$

\begin{tabular}{|c|c|c|c|}
\hline Candidate & Party & Votes & Percentage \\
\hline John Kufuor & New Patriotic Party (NPP) & $3,131,739$ & 48.17 \\
\hline John Atta Mills & National Democratic Congress (NDC) & $2,895,575$ & 44.54 \\
\hline Edward Mahama & People's National Convention (PNC) & 189,659 & 2.92 \\
\hline George Hagan & Convention People's Party (CPP) & 115,641 & 1.78 \\
\hline Augustus Obuadum Tano & National Reform Party & 78,629 & 1.21 \\
\hline Dan Larty & Great Consolidated Popular Party & 67,504 & 1.04 \\
\hline Charles Wereko-Brobby & United Ghana Movement & 22,123 & 0.34 \\
\hline Invalid Votes & & 104,214 & - \\
\hline Total & & $6,605,084$ & 100 \\
\hline
\end{tabular}

Source: African Elections Data base

Since none of the contestants secured $50+1 \%$ of the votes to emerge as an outright winner in accordance with Article 63 (3)(4)(5) of the 1992 Constitution, there had to be a run-off between John Kufuor and Atta Mills on December 28 $8^{\text {th }}, 2000$. In it, John Kufuor of the NPP had 3, 631, 263 or $56.90 \%$ of the votes to win as against 2,750,124 accounting for $43.10 \%$ of the votes. The election was hard fought ( Commonwealth Observers Report, 2008, p.43).

This second Presidential Run-off Election in the political history of Ghana was fierce and among other factors, the desire for change in the polity won victory for the then major opposition party, the NPP. It however, marked a turning point in the political history of Ghana by being the first time since independence that power had changed peacefully from one civilian to another. Esew (2001:258) captures it vividly thus: Ghanaians have voted for a positive change and besides, this is the first time since independence that they have voted for a change of government via free and fair elections. The election marked the first transfer of power via the ballot box in the country's political history. In other words it was a peaceful transfer of political power from one party to another.

\section{Presidential Election Round One}

Having won the Presidential Elections for two consecutive times in 2000 and 2004, just like J.J. Rawlings had done earlier, John Kufuor, the incumbent was disqualified from going for a third term in the December $7^{\text {th }}$ General Elections. The Presidential ticket of the NPP went to Nana Akuffo Addo while Prof John Evans Atta Mills still picked that of the NDC. For Atta Mills this was his third time contesting on the ticket of the NDC which had been in opposition since he lost to John Kufuor of the NPP in 2000 (Amoah,2009:174). At the end of the first round, none of the candidates had secured $50+1 \%$ votes.

Wikipedia: The Free Encyclopedia point out that

Turn-out on election-day was very high. Since few votes were expected for other candidates than those of the two largest parties, a first-round victory for Akuffo Addo or Mills was seen as possible... (BBC News 2008-12-08 Retrieved 2008-12-10. Cited).

Table showing Results of the First Round of the 2008 Presidential Election

\begin{tabular}{|l|l|l|l|}
\hline Candidate & Party & Votes & Percentage \\
\hline John Atta Mills & National Democratic Congress & 4056634 \\
\hline Nana Akuffo Addo & New Patriotic Party & 4159439 & 47.92 \\
\hline Kwesi Nduom & Convention People's Party & 113,494 & 49.13 \\
\hline Edward Mahama & People's National Convention & 73,494 & 1.34 \\
\hline Emmanuel Ansah-Antwi & Democratic Freedom & 27,889 \\
\hline Kwasi Amoafo Yeboah & Independent & 19342 & 0.87 \\
\hline Thomas Ward Brew & Democratic People's Party & 8,653 & 0.33 \\
\hline Kwabena Adjei & Reformed Patriotic Democrats & 6,889 & 0.23 \\
\hline Valid Votes & & $8,465,834$ \\
\hline Invalid or blank votes & & 205,438 \\
\hline Totals & & $\mathbf{8 , 6 7 1 , 2 7 2}$ \\
\hline
\end{tabular}

Source: Electoral Commission Ghana, 2008

The table above shows that the $7^{\text {th }}$ December, 2008 Presidential Election failed to produce an outright winner. Consequently, December $28^{\text {th }}$ was set to be the Run-off Election between the two front runners, Nana Akuffo Addo and John Attah Mills of the NPP and NDC respectively.. Wikipedia puts it succinctly thus:

The second round was re-run on $28^{\text {th }}$ December, 2008 but due to logistics problem, like the distribution of voting materials , the Tain District (in the Brong Ahafo Region) alone had its run-off election on January $2^{\text {nd }}$, 2009 making it a second run-off election and voting thrice for the Presidential election. 
Even though 'change' was a popular theme on the campaign trail, the intensity of the difficult choice between two exceptionally good candidates from the ruling and opposition parties effectively polarized the country into two nearly equal halves along the lines of the two dominant parties, NPP and NDC, in the fray as was reflected in the electoral results (Amoah, 2009:175).

At the end of the December $28^{\text {th }}$ run-off no winner had emerged because Prof. John Evans Atta Mills of the NDC had polled 4,521,032 representing 50.23\% while Nana Akuffo-Addo obtained 4,480, 446 or 49.77\%.

\section{The Peculiarity of December, 2008 / January, 2009 Run-off}

With the deadlock after the first Presidential Run-off Election on December, 2008, Tain Constituency in the Brong Ahafo Region held the ace for the race. The scenario was that the ruling NPP had just lost its Parliamentary seat there to the NDC, then major opposition party. Again, in the first round of the Presidential Election on December $7^{\text {th }}$, the NDC had polled 16,000 votes as against NPP's 14,000. It must be pointed out that Tain was a 50,000-voter Constituency. According to the Electoral Commissioner (EC), therefore, the game was open and that either of the two parties could eventually win the election based on the votes secured in Tain. All eyes were, therefore, on Tain. As the saying goes 'all roads lead to Rome', during the waiting period, all political stalwarts and foot soldiers of the NPP and NDC made their way to Tain. The first to get there was J.J. Rawlings, the founder and leader of the opposition NDC together with the Party's flag bearer, John Atta Mills. Tain was so charged that the incumbent, President John Agyekum Kufuor, and the NPP flagbearer, Nana Akuffo Addo, had to cut short their trip to Tain because of security challenges.

As can be seen above in all the previous run-offs winners had emerged. In the December $28^{\text {th }}$ run off however, John Atta Mills had a slight edge over Nana Akuffo Addo with Tain Constituency outstanding. However, following the voting on December $28^{\text {th }}$, Mills led by a slim margin causing the Electoral Commission to State it would not announce Mills as the winner until after the election re-run in Tain (Google News Associated Press 28-12-30 Retrieved 2009-01-04). As pointed out earlier, this was the first time Presidential Run-off Election was going for the third round.

The Chairman of the EC pointed out that there were electoral irregularities in the Ashanti Region which had been substantiated by the opposition NDC and similarly the ruling NPP also had allegations against the NDC in the Volta Region but had not brought any evidence yet. He then told the whole nation on radio and Television (Adom FM, Joy FM, and Peace FM) that the NPP could bring their evidence to be looked into because the name of the game was 'fact'.

Later on however, NPP poll agents some of whom had matchet wounds, swollen eyes and plastic on their bodies trooped to the headquarters of the EC in Accra as evidence of prevention of effectively monitoring the election for their party. The EC on its part maintained that such acts of brutality were criminal in nature and should, therefore, be reported to the police instead.

Wikipedia Free Encyclopedia opines that fear of Election-day violence caused the NPP to file a law suit seeking to delay the voting in Tain as it claimed that the atmosphere in the rural district was not conducive to free and fair election. The court denied the NPP's injunction request and said it would only hear the case on January 5,2009 . In response, the NPP called on its supporters to boycott the vote at Tain. In the long run, the opposition NDC's candidate Prof. John Evans Atta Mills became victorious with $50.23 \%$ as against Nana Akuffo Addo of the NPP who polled $49.77 \%$. This marked the second time in the Fourth Republic that an incumbent government had to hand over power to the major opposition party.

Reuters (2009) captures it graphically with the caption,

'Nana boycotts election in Tain where Mills wins overwhelming majority of votes and (consequently) was declared winner on January 3, 3009'.

As pointed out earlier one of the factors that made the 2008 Presidential a do-or-die affair was the desire of the NDC to wrestle back power after being in opposition for eight years. It must also be noted that the stakes were high because oil had just discovered in the Western Region during the twilight of the Kufuor administration.

Events in Ghana during the various run-off elections epitomized the fragility of the post colonial state in Africa and that Ghana was also not insulated from post-election crisis as experienced in some countries like Kenya, Zimbabwe and Nigeria to mention but a few.

\section{Conclusion}

The paper critically examined the 2008 Presidential Run- off Election in Ghana. Even though it was not the first time that run-offs were being held in Ghana, it created lots of anxiety since it had to run for three rounds before a winner, Prof John Evans Atta Mills, finally emerged. The results of the December, 2008 General Elections also indicated that so far there had been two successful and peaceful handing over of power from one civilian government to another- a feat difficult to achieve in the immediate post-independence years when the military truncated the democratic process. 
Ghana, it must be remembered, is a colonial creation and its fragility, therefore, must not be in doubt. Care must consequently be taken not to use elections to set the country ablaze.

Lots of lessons must be learnt from the December 2008/January, 2009 Presidential Run-off Elections among which are the following:

The do-or-die approach to elections must be discouraged. Ghana for now is blessed with two major political parties, NPP and NDC, that are capable of winning elections and this must be exploited to the advantage of the whole country. These two parties provide alternatives for the electorate and if we eschew ethnicity we can always vote for the one that can provide the dividends of democracy. Ghana is again lucky that any time one of them is in power the other provides a formidable opposition which is very vital for checking the excesses of power by hitherto single dominant political party. Remember what Dr Kwame Nkrumah once said, 'only the best is good enough for Africa'. In our case, only the best is good enough for Ghana.

There is also the issue of 'winner take all' in our political system. Ghanaians must seriously think of an electoral system that is akin to our tradition and culture. Besides, electioneering campaigns should be issuebased and not personality-based whereby opponents are openly insulted and degraded.

\section{References}

[1] Amoah, Michael, (2009): 'The Most Difficult Decision Yet: Ghana's 2008 Presidential Elections', African Journal of Political Science and International Relations, April 2009, Vol 3(4), pp174-181

[2] Adom, FM, Joy FM, Peace FM 28-12-30

[3] Ask.com 26-02-2014@22.00hrsGMT

[4] Bain, C.W. (1964) "Election" Dunner J. (Ed), 1964. Dictionary of Political Science, New York Philosophical Library

[5] BBC News 2008-12-08 Retrieved 2008-12-10

[6] Bouton, Laurent (2013) 'A Theory of Strategic Voting in Run-Off Elections', American Economic Review 2013, 103(4) 12481288 .

[7] Commonwealth Observers Report, 2008 P. 43

[8] Esew, N.G, (2011) A Critical Analysis of Transition to Civil Rule in Nigeria and Ghana (1960 - 2000)

[9] Eya, Nduka (2003), Electoral Processes, Electoral Malpractices and Electoral Violence, Enugu, Sages Publications Nigeria Ltd.

[10] Google News Association Press 28-12-30 Retrieved 2009-01-04

[11] Gwinn R. and Nortan P. (1992) The New Encyclopedia Britannica, Chicago: University of Chicago Press.

[12] Inokoba, P.K and Kumokor, Isaac (2011) 'Electoral Crisis, Governance and Democratic Consolidation in Nigeria', Journal of Social Science, 27(2) 139-148(0000).

[13] Johari, J.C. (2003) Principles of Modern Political Science, New Delhi, Sterling Publication Private Ltd.

[14] McKenzie, W.J.M. (1972) Encyclopedia of the Social Sciences Nos 5 and 6, London, McMillan and Free Press.

[15] Oddih, Michael (2007) "Electoral Fraud and the Democratic Process: Lessons from the 2003 Elections' in Elections and the Future of Democracy in Nigeria by Attahiru Jega and Okechukwu Ibeanu (Eds) 2007, A Publication of the Nigerian Political Science Association.

[16] Reuers, January 3, 2009

[17] Simpser, Alberto (2013) Why Governments and Parties Manipulate Elections: Theory, Practice and Implications, Cambridge, Cambridge University Press.

[18] Uslegal.com/r/run-off election

[19] Wikipedia the Free Encyclopedia

[20] World Book Encyclopedia (2008) Vol. 6 Chicago, Work Book. 